\title{
The Association of Sphenoidal Encephalocele and Right Anophthalmia with Septo-Optic Dysplasia: A Case Report
}

\author{
Septo-Optik Displazi ile Birlikte Sfenoidal Ensefalosel ve Săg Enoftalmi \\ Birlikteliği: Bir Olgu Sunumu
}

Fatih Serhat EROL, Necati UCLER, Metin KAPLAN, Ilhan YILMAZ

Firat Univertsity, Faculty of Medicine, Department of Neurosurgery, Elazig, Turkey

Correspondence address: Fatih Serhat EROL / E-mail: fserol@yahoo.com

\begin{abstract}
Septo-optic dysplasia (SOD) is an extremely rare congenital anomaly, characterized with optic nerve hypoplasia and absence of septum pellucidum and/or pituitary dysfunction. In addition to classical findings of SOD, we report for the first time an 11-year-old boy, with encephalocele extending to the right sphenoidal sinus, right anophthalmia and normal pituitary functions. Despite all the major anomalies, the patient's presenting symptoms were very few and during the 11-year period the SDO had caused no complaints in our case. These findings show that the SOD course may be fairly benign. No neurological problem was encountered in the patient's follow-up, except headache. We believe that SOD should be kept in mind because of its rarity and the severity of its combined pathologies.
\end{abstract}

KEYWORDS: Septo-optic dysplasia, Sphenoidal encephalocele, Anophthalmia, Congenital

öz

Septo-optik displazi (SOD) optik sinir hipoplazisi ve septum pellusidium yokluğu ve/veya hipofiz disfonksiyonu ile karekterize çok nadir bir konjenital anomalidir. SOD nin bu klasik bulgularına ek olarak, biz literatürde ilk kez normal hipofiz fonksiyonlarına sahip, sağ enoftalmisi ve sağ sfenoidal sinüse kadar uzanan ensefaloseli olan 11 yaşında bir erkek çocuğu bildirdik. Bütün bu büyük anomalilere karşı, hastamızda bu semptomların çok az bir kısmı bulunmakta idi ve 11 yıllık dönemde SOD her hangibir şikaye neden olmamıştı. Bu bulgular SOD'nin oldukça benign olabileceğini göstermektedir. Hastamızın takiplerinde baş ağrısı dışında herhangibir nörolojik problemle karşılaşıımamıştır. Biz SOD’nin oldukça nadir olmasına ve eşlik ettiği patolojilerin şiddetine rağmen akılda tutulması gerektiğini düşünüyoruz.

ANAHTAR SÖZCÜKLER: Septo-optik displazi, Sfenoidal ensefalosel, Anoftalmi, Konjenital

\section{INTRODUCTION}

SOD was first defined by de Morsier and known as optic nerve hypoplasia, absence of septum pellicudium and/or pituitary dysfunction (4). This rare anomaly is seen at equal prevelance in both sexes, and its reported incidence is 1:10.000 births $(10,5)$. SOD has a variable phenotypic expression (13). In addition to growth retardation, seizures, visual impairment, sleep disorder, precocious puberty, anosmia, sensorineural hearing loss, and cardiac anomalies frequently seen in SOD (14), we report a case without these signs, excep for right blindness due to right anophthalmia, and our case was noteworthy in this regard.

\section{CASE REPORT}

An 11-year-old boy was admitted to our clinic due to headache. We learned from the patient's parents that the patient had absence of the right eye at birth, was operated on when 6 months old for simple blepharoplasty unrelated to SOD, and showed normal growth and development. Axial T2- weighted magnetic resonance imaging (MRI) showed right anophthalmia, optic nerve atrophy, and colpocephaly (Figure 1A). T2- and T1-weighted MRIs showed a defect at the base of the sella, and an encephalocele that was extending through the suprasellar cistern to the right sphenoidal sinus, with a smooth appearance and isointensity with cerebrospinal fluid (CSF). Its size was about $4 \times 2.5 \mathrm{~cm}$ (Figure 1B) and there was agenesis of the corpus callosum and absence of septum pellucidum (Figure 1C). Computed tomography (CT) showed a defect at the base of the sella and an isodense encephalocele with CSF extending to the right sphenoidal sinus (Figure 2).

There was no pathology in the patient's hormonal profile. The patient's neurological examination was otherwise normal. The patient was followed-up as there were no local and systemic problems due to the presenting pathologies.

\section{DISCUSSION}

SOD has two basic features: optic nerve hypoplasia and atrophy of septum pellucidum. Pituitary hormone dysfunction 

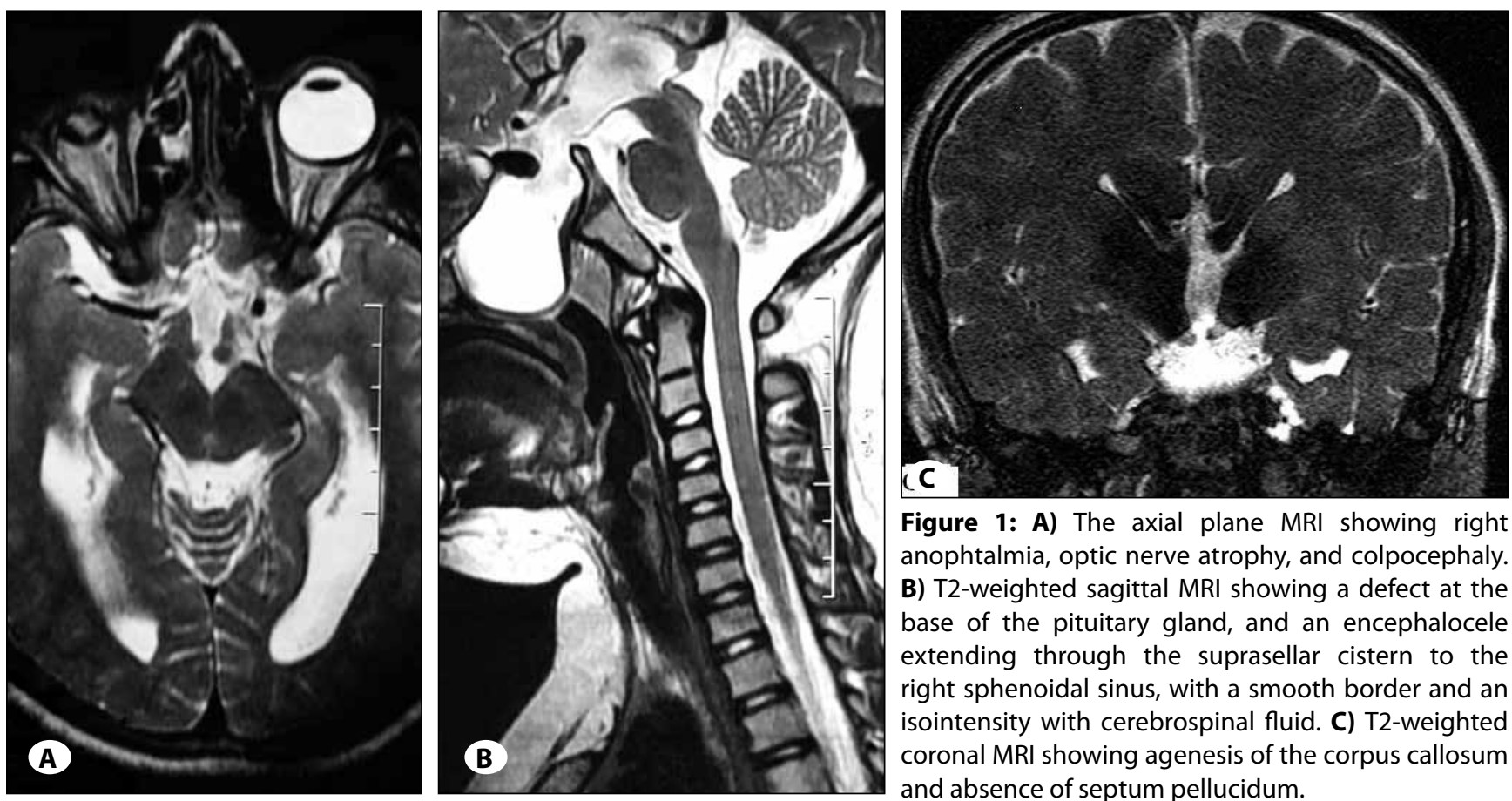

Figure 1: A) The axial plane MRI showing right anophtalmia, optic nerve atrophy, and colpocephaly. B) T2-weighted sagittal MRI showing a defect at the base of the pituitary gland, and an encephalocele extending through the suprasellar cistern to the right sphenoidal sinus, with a smooth border and an isointensity with cerebrospinal fluid. C) T2-weighted coronal MRI showing agenesis of the corpus callosum and absence of septum pellucidum.

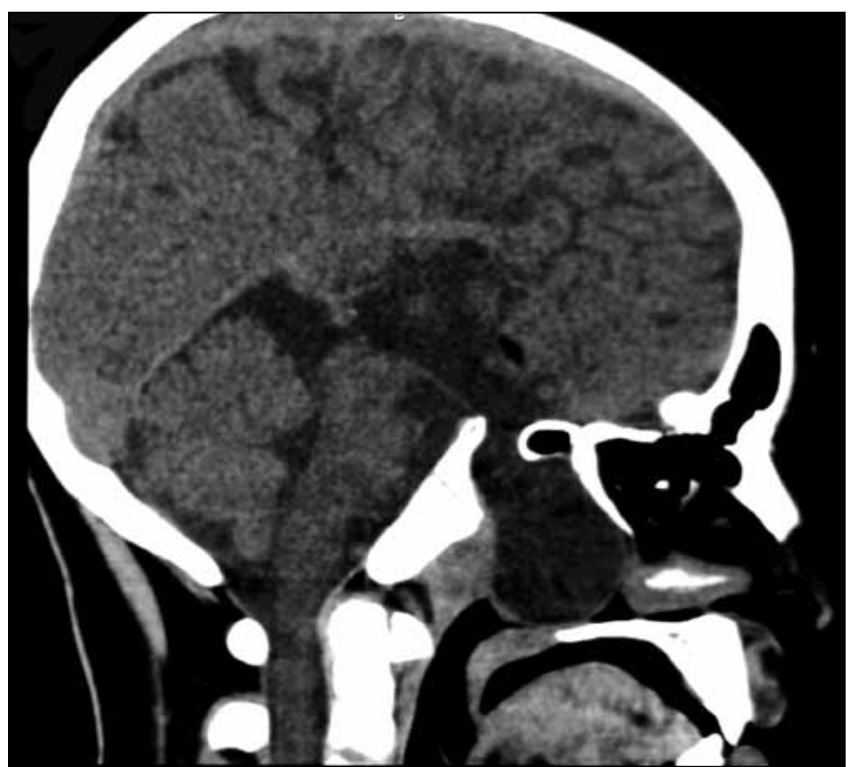

Figure 2: Computed tomography image showing a defect at the sella base and an isodense encephalocele with CSF extending to the right sphenoidal sinus.

is also important. Our case had no pituitary hormonal dysfunction but an anatomical defect was present at the sella base. However, endocrine disorders are found in $40 \%$ of the patients with SOD (9). The main reported clinical findings were hypopituitarism (62-80\%), with growth hormone deficiency being the commonest endocrine abnormality, and visual impairment (23\% significant visual impairment) and developmental delay [more common in children with bilateral (57\%) as opposed to unilateral optic nerve hypoplasia (32\%)]
(7). Seizures, developmental delay and cerebral palsy are the most frequent neurological associations (6).

The presence of SOD in a patient with multiple pathologies such as encephalocele, anophthalmia, agenesis of corpus callosum, a defect at the base of the pituitary gland, and colpocephaly without causing any neurological deficits or pituitary impairments is an interesting part of our SOD case. The encephalocele in our case is extended to the right sphenoidal sinus, and this is another interesting feature of our case. Recently, Periakarppan et al reported SOD associated with an encehalocele localized to the fronto-ethmoidal region (11). Our patient is reported as the second encephalocele case and seems to be a basilar encephalocele.

Right anophthalmia with SOD is another important feature of our case. Severe bilateral eyes anomalies (anophthalmia, microphthalmia) and anterior pituitary hypoplasia associated with defects of corpus callosum were defined in SOX2 mutations (1). However, genetic anomalies were defined only in one percent of patients and SOD etiology could not identified in the most of patients (14). Mutations in HESX1 and SOX2 genes were found (3-12). Mutations in SOX2 genes are found in $15 \%$ of anophthalmia cases and these mutations mainly lead to bilateral anophthalma (15). Lubinsky et al considered that neurological anomalies in SOD might be caused by secondary vascular disorders (8). Additionally, an insult (hypoperfusion/infection) to the brain during the late 7th or 8th week of gestation may form the embryologic basis for the association of SOD and schizencephaly (2).

Although it seems that SOD is easily diagnosed clinically and radiologically, the disorder needs to be better known because of the variable phenotypical appearance and 
other accompanying anomalies as in our case. For example, Morishima and Aranoff (9) reported the full spectrum of findings in $30 \%$ of SOD cases, hypopituitarism in $62 \%$, and absence of septum pellucidum in $60 \%$.

In conclusion, SOD may have multiple phenotypical presentations and should be kept in mind in the differential diagnosis of cases with anophthalmia and encephalocele extending to the sphenoidal sinus.

\section{REFERENCES}

1. Alatzoglou KS, Kelberman D, Dattani MT: The role of SOX proteins in normal pituitary development. J Endocrinol 200: 245-258, 2009

2. Barkovich AJ, Norman D: MR of schizencephaly. AJNR Am J Neuroradiol 9:297-302, 1988

3. Dattani MT, Martinez-Barbera JP, Thomas $P Q$, Brickman JM, Gupta R, Mårtensson IL, Toresson H, Fox M, Wales JK, Hindmarsh PC, Krauss S, Beddington RS, Robinson IC: Mutations in the homeobox gene HESX1/Hesx1 associated with septo-optic dysplasia in human and mouse. Nat Genet 19:125-133, 1998

4. De Morsier G: Etudes sur les dysraphies cranioencéphaliques: III. Agénésie du septum pelucidum avec malformation du tractus optique. La dysplasie septoöptique. Schweiz Arch Neurol Psychiatr 77:267-292, 1956

5. Elster AB, McAnarney ER: Maternal age re septo-optic dysplasia. J Pediatr 94:162-163, 1979

6. Garcia ML, Ty EB, Taban M, David Rothner A, Rogers D, Traboulsi El: Systemic and ocular findings in 100 patients with optic nerve hypoplasia. J Child Neurol 21:949-956, 2006
7. Haddad NG, Eugster EA: Hypopituitarism and neurodevelopmental abnormalities in relation to central nervous system structural defects in children with optic nevre hypoplasia. J Pediatr Endocrinol Metab 18:853-858, 2005

8. Lubinsky MS: Hypothesis: Septo-optic dysplasia is a vascular disruption sequence. Am J Med Genet 69:235-236, 1997

9. Morishima A, Aranoff GS: Syndrome of septo-optic-pituitary dysplasia: The clinical spectrum. Brain Dev 8:233-239, 1986

10. Patel L, McNally RJ, Harrison E, Lloyd IC, Clayton PE: Geographical distribution of optic nerve hypoplasia and septo-optic dysplasia in Northwest England. J Pediatr 148: 85-88, 2006

11. Periakaruppan A, Pendharkar HS, Gupta AK, Thomas B, Kesavdas C: Septo-optic dysplasia with encephalocele. J Clin Neurosci 16:1665-1667, 2009

12. Sato N, Kamachi Y, Kondoh H, Shima Y, Morohashi K, Horikawa $\mathrm{R}$, Ogata T: Hypogonadotropic hypogonadism in an adult female with a heterozygous hypomorphic mutation of SOX2. Eur J Endocrinol 156:167-171, 2007

13. Spinosa MJ, Liberalesso PB, Vieira SC, Löhr A Jr: De Morsier syndrome associated with periventricular nodular heterotopia: Case report. Arq Neuropsiquiatr 65:693-696, 2007

14. Webb EA, Dattani MT: Septo-optic dysplasia. Eur J Hum Genet 18(4):393-397, 2010 Epub 2009 Jul 22

15. Williamson KA, Hever AM, Rainger J, Rogers RC, Magee A, Fiedler Z, Keng WT, Sharkey FH, McGill N, Hill CJ, Schneider A, Messina M, Turnpenny PD, Fantes JA, van Heyningen V, FitzPatrick DR: Mutations in SOX2 cause anophthalmiaesophageal-genital (AEG) syndrome. Hum Mol Genet 16: 1413-1422, 2006 